\title{
A súlyos kombinált immundefektusok újszülöttkori szúroovizsgálata
}

\author{
Erdős Melinda dr., ${ }^{1,2}$
}

\begin{abstract}
${ }^{1}$ Debreceni Egyetem, Általános Orvostudományi Kar, Infektológiai és Gyermekimmunológiai Tanszék, Debrecen ${ }^{2}$ St. Giles Laboratory of Human Genetics of Infectious Diseases, The Rockefeller University, New York, NY, USA
\end{abstract}

\begin{abstract}
A súlyos kombinált immundeficientia az első immunhiányos betegség, amely 2010-ben a világon elsóként az Egyesült Államokban bekerült az újszülöttkori szűrőprogramba. Hazánkban az újszülöttkori szưrés bevezetése a kötelezően alkalmazott BCG-oltás miatt is döntő fontosságú, hiszen negatív családi anamnézisű beteg újszülött esetében az oltás halálos kimenetelü fertőzéshez vezethet. A közlemény a súlyos kombinált immundefektusok újszülöttkori szűrővizsgálatának bevezetési lehetőségeit elemzi, és összefoglalja az eddigi tapasztalatokat és eredményeket.

Orv Hetil. 2018; 159(23): 948-956.
\end{abstract}

Kulcsszavak: súlyos kombinált immundeficientia, újszülöttkori szürés, TREC

\section{Neonatal screening of severe combined immunodeficiencies}

\begin{abstract}
Severe combined immunodeficiency is the first immune deficiency disorder which was included in the newborn screening program in the United States in 2010. In Hungary, newborn screening for severe combined immunodeficiencies is crucial because of the routine BCG vaccination, as in the case of an affected newborn with negative family history, the vaccine may lead to fatal BCG-itis. This paper analyzes the possibilities of introducing newborn screening for severe combined immunodeficiencies and summarizes current experiences and results.
\end{abstract}

Keywords: severe combined immunodeficiency, newborn screening, TREC

Erdős M. [Neonatal screening of severe combined immunodeficiencies]. Orv Hetil. 2018; 159(23): 948-956.

(Beérkezett: 2018. február 27.; elfogadva: 2018. március 20.)

\begin{abstract}
Rövidítések
$\mathrm{ADA}=$ adenozin-dezamináz; $\mathrm{ALC}=$ (absolute lymphocyte count) abszolút lymphocyta-szám; DNS = dezoxiribonukleinsav; HSCT $=$ (hematopoietic stem cell transplantation) haematopoeticusőssejt-transzplantáció; IL = interleukin; PID = primer immundeficientia; RT-PCR $=$ (real-time polymerase chain reaction) valós idejű polimeráz-láncreakció; $\mathrm{RUSPCC}=\mathrm{Re}$ commended Uniform Screening Panel of Core Conditions; SCID $=$ (severe combined immunodeficiency) súlyos kombinált immundeficientia; TCL $=(\mathrm{T}$-cell lymphopenia $)$ T-sejtes lymphopenia; TREC $=($ T-cell receptor excision circle $)$ T-sejtreceptor-kivágás-kör
\end{abstract}

\footnotetext{
"Periculum est in mora" (Livius)

Nincs még egy primer immundeficientia (PID), amelyben a korai felismerés oly mértékben meghatározza a beteg sorsának kimenetelét, mint a SCID (severe combined immunodeficiency, súlyos kombinált immundeficientia)!
}

Az újszülöttkori szûrővizsgálatok célja a fenotípusprevenció, azaz a betegség preszimptomatikus időszakban történő korai felismerése és hatékony kezelése. A SCID és a veleszületett T-sejtes lymphopenia (T-cell lymphopenia, TCL) minden tekintetben megfelel azon kritériumoknak, amelyek teljesülése szükséges ahhoz, hogy egy betegség az újszülöttkori rutin szürôvizsgálati programban szereplő betegségek listájára kerülhessen [1]. Az Advisory Committee on Heritable Disorders in Newborns and Children (USA) által meghatározott és a WilsonJungner-klasszifikációt is figyelembe vevő kritériumok a következők $[2,3]$ :

1) a betegség súlyos lefolyású,

2) a betegségnek nincsenek jellemző újszülöttkori klinikai tünetei,

3) a betegség az orvosi szakirodalomban jól dokumentált, 
4) a betegség viszonylag gyakori,

$5)$ populációs szintú bevezetését megelőzően a tervezett szürővizsgálati módszert tesztelték,

6) rendelkezésre áll megalapozott, kellően szenzitív és specifikus, könnyen hozzáférhető és olcsó szűrőmódszer, amely mindenben megfelel a populációs szintű szürővizsgálatokkal szemben támasztott követelményeknek,

7 ) létezik hatékony terápia, amelynek idejekorán történő alkalmazásával a súlyos tünetek kialakulása megelőzhető, illetve amelynek hiányában tartós egészségkárosodás alakul ki,

8 ) a kezelés mindenki számára hozzáférhető,

9) ha a betegség spektruma széles, pontosan meghatározott azon betegek csoportja, akik számára a kezelés bevezetése a leginkább előnyös.

Néhány kivételtől eltekintve a SCID és a TCL újszülöttkorban és fiatal csecsemő korban teljesen tünetmentes. Az idejekorán történő felismerés ugyanakkor döntő jelentőségű a korai, még tünetmentes állapotban elkezdett életmentő kezeléshez. Mindezek miatt a primer immundeficientiák prenatalis diagnosztikájának és az újszülöttkori szűrés bevezetésének kérdése már régóta a figyelem középpontjában áll [4]. A SCID volt az első immunhiányos betegség, amely 2010-ben a világon elsőként az Egyesült Államokban bekerült az újszülöttkori szürőprogramba (Recommended Uniform Screening Panel of Core Conditions, RUSPCC). Napjainkban az Egyesült Államok 26 tagállamában és több európai országban (Egyesült Királyság, Franciaország, Izrael) a SCID és a TCL az újszülöttkori szúrővizsgálatok része.

\section{SCID és TCL}

A SCID az immunrendszert érintő betegségek azon csoportja, amelyben mind a sejtes, mind a humorális (antitestes) immunitás súlyosan károsodott. SCID-ben a lymphocyták száma általában (de nem minden esetben!) csökkent, funkciójuk azonban minden esetben kóros. Az öröklődésmenet az esetek több mint 50\%-ában X-kromoszómához kötött, és a betegség fiúkban háromszor gyakrabban fordul elő. A megszületéskor tünetmentes újszülöttek kifejezetten fogékonyak opportunista és klasszikus fertőzésekre, amelyek többnyire egyéves kor előtt halálhoz vezetnek, ha a betegséget újszülött- vagy fiatal csecsemő korban nem ismerik fel [5].

\section{Klinikai manifesztációk}

A genetikai heterogenitás ellenére a csökkent T-sejtes immunitás miatt a klinikai fenotípus nagyon hasonló. A születéskor észlelt tünetmentesség ellenére immunlaboratóriumi vizsgálattal a $\mathrm{T}$-sejtek hiánya vagy funkcionális defektusa már ekkor nyilvánvaló. SCID-ben a súlyos, életveszélyes légúti, gastrointestinalis vagy idegrendszeri fertőzések már az első élethetekben, de legkésőbb 3-4 hónapos korban, az anyai ellenanyagok kiürülésével egy időben jelentkeznek. Jellemzőek a visszatérő, opportu- nista fertőzések, mint például a Pneumocystis jirovecii okozta pneumonia, a perzisztáló, masszív soor, a perinealis candidiasis, a krónikus vírusinfekciók, a vakcinációt követő disszeminált BCG-fertőzés és a visszatérő hasmenés, amelynek egyik oka az élő rotavírust tartalmazó oltóanyag adása is lehet [6]. A virális kórokozók között a leggyakoribbak a herpeszvíruscsoport tagjai (HSV, VZV, EBV, CMV), a több szerv egyidejü megbetegedését okozó adenovírusok és a perzisztáló fertőzést okozó parainfluenzavírusok. Típusos esetben a perzisztáló infekciók, a krónikus hasmenés és a fejlődésben való visszamaradás jelzik, hogy a beteg SCID-ben szenved. A betegségre tehát minden gyarapodási zavar miatt kezelt fiatal csecsemő esetében gondolni kell, különösen, ha egyidejưleg infekció és hasmenés is észlelhető. Mellkasröntgenfelvételen thymusárnyék általában nem látható, a nyirokcsomók hypoplasiásak. Az elkülönítő diagnosztikában elsősorban a HIV-fertőzés és a veleszületett anyagcsere-betegségek jönnek szóba [5].

\section{Laboratóriumi eltérések, molekuláris genetika}

A SCID különböző genetikai hátterű betegségek csoportja, amelyek mögött az adaptív immunitás elemeinek érését szabályozó gének hibája áll. Az immunológiai laboratóriumi, az enzim- és a molekuláris genetikai vizsgálatok alapján a SCID több formája különíthető el (1. táblázat) [1]. A leggyakoribb SCID-formában, a perifériás vérben nem mutatható ki T-sejt, B-sejtek azonban jelen vannak. Ez a $\mathrm{T}^{-} \mathrm{B}^{+}$SCID-forma az összes SCID-eset felében fordul elő. A betegség ezen formájában az IL2-receptor-gén (IL2RG) mutációja miatt nem szintetizálódik az IL2R gamma-lánca, az úgynevezett „közös gamma-lánc”, amely nemcsak az IL2R, hanem több más citokinreceptor komponense, emiatt vezet a defektus súlyos immunhiányos állapothoz [5].

\section{Terápia}

A SCID kezelési lehetőségei a következők [7]: 1) allogén haematopoeticusőssejt-transzplantáció (bematopoietic stem cell transplantation, HSCT) HLA-azonos rokon vagy nem rokon donor, haploidentikus szülői donor vagy köldökzsinórvér felhasználásával; 2) enzimpótló kezelés a SCID adenozin-dezamináz (ADA)-hiánnyal járó formájában; 3) génterápia közös $\gamma$-lánc-deficientia (XSCID) és ADA-SCID esetében; és 4) fejlesztés alatt vannak vírusvektort nem használó génkorrekciós eljárások is $[8,9]$. Fontos hangsúlyozni, hogy a kezeléssel a legkedvezőbb eredmények akkor érhetők el, ha a betegséget még a tünetmentes időszakban felismerik. Ha a donor hisztokompatibilis (az esetek 20-30\%-ában), a kezelés a betegek közel 100\%-ában gyógyulást eredményez. Az elmúlt évtizedek tapasztalatai azt is mutatják, hogy haploidentikus, szülőtől származó, T-sejt-depletált csontvelővel is igen jó terápiás eredmény érhető el. A SCID-ben szenvedő csecsemők többségében az adaptív immunitás 
1. táblázat |A SCID és a CID klasszifikációja a patomechanizmus, az immunfenotípus és a géndefektus alapján

\begin{tabular}{|c|c|c|c|c|c|c|}
\hline Mechanizmus/Betegség & $\mathrm{T} / \mathrm{B} / \mathrm{NK}$ & Gén & Lokalizáció & Öröklődés & Fehérje & Nem immunológiai manifesztációk \\
\hline \multicolumn{7}{|c|}{ Károsodott citokinmediált szignalizáció és korai lymphoid progenitor fejlődés } \\
\hline Közös gamma-lánc-deficientia & $\mathrm{T}^{-} \mathrm{B}^{+} \mathrm{NK}^{-}$ & IL2RG & $\mathrm{Xq13.1}$ & $\mathrm{XL}$ & $\begin{array}{l}\text { Közös gamma- } \\
\text { lánc }\end{array}$ & \\
\hline$J A K 3$-deficientia & $\mathrm{T}^{-} \mathrm{B}^{+} \mathrm{NK}^{-}$ & JAK3 & $19 \mathrm{p} 13.1$ & AR & Janus-kináz-3 & \\
\hline IL7Ra-lánc-deficientia & $\mathrm{T}^{-} \mathrm{B}^{+} \mathrm{NK}^{+}$ & IL7RA & $5 \mathrm{p} 13$ & AR & $\begin{array}{l}\text { IL7- és TSLP- } \\
\text { receptor- } \alpha \text {-lánc }\end{array}$ & \\
\hline \multicolumn{7}{|c|}{ Pre-T-sejt-receptor-deficientiák } \\
\hline \multicolumn{7}{|l|}{ V(D)J-rekombinációs zavarok } \\
\hline RAGl-deficientia & $\mathrm{T}-\mathrm{B}^{-} \mathrm{NK}^{+}$ & RAGl & $11 \mathrm{p} 13$ & $\mathrm{AR}$ & RAGl & \\
\hline RAG2-deficientia & $\mathrm{T}^{-} \mathrm{B}^{-} \mathrm{NK}^{+}$ & RAG2 & $11 \mathrm{p} 13$ & AR & RAG2 & \\
\hline Artemis-deficientia & $\mathrm{T}^{-} \mathrm{B}^{-} \mathrm{NK}^{+}$ & DCLREIC & $10 \mathrm{pl} 3$ & AR & Artemis & Radioszenzitivitás \\
\hline DNA-PKcs-deficientia & $\mathrm{T}^{-} \mathrm{B}^{-} \mathrm{NK}^{+}$ & PRKDC & $8 \mathrm{q} 11.21$ & $\mathrm{AR}$ & DNA-PKcs & Radioszenzitivitás \\
\hline DNA ligáz-IV-deficientia & $\mathrm{T}^{-} \mathrm{B}^{-} \mathrm{NK}^{+}$ & LIG4 & $13 q 33.3$ & $\mathrm{AR}$ & DNA ligáz-IV & $\begin{array}{l}\text { Radioszenzitivitás, dysmorph facies, } \\
\text { microcephalia, növekedési retardáció, } \\
\text { megkésett pszichomotoros fejlődés }\end{array}$ \\
\hline Cernunnos/XLF deficientia & $\mathrm{T}^{-} \mathrm{B}^{-} \mathrm{NK}^{+}$ & NHEJl & $2 q 35$ & AR & Cernunnos/XLF & $\begin{array}{l}\text { Radioszenzitivitás, dysmorph facies, } \\
\text { microcephalia, növekedési retardáció, } \\
\text { megkésett pszichomotoros fejlődés }\end{array}$ \\
\hline \multicolumn{7}{|c|}{ Károsodott pre-T-sejt-receptor-szignalizáció } \\
\hline$C D 3 \delta$-deficientia ${ }^{\#}$ & $\mathrm{~T}^{-} \mathrm{B}^{+} \mathrm{NK}^{+}$ & CD3D & $11 q 23$ & AR & CD3 $\delta$ & \\
\hline CD3 $\varepsilon$-deficientia ${ }^{\# \mathbb{T}}$ & $\mathrm{T}^{-} \mathrm{B}^{+} \mathrm{NK}^{+}$ & CD3E & $11 q 23$ & AR & $\mathrm{CD} 3 \varepsilon$ & \\
\hline 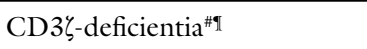 & $\mathrm{T}^{-} \mathrm{B}^{+} \mathrm{NK}^{+}$ & CD3Z & $\operatorname{lq} 24.2$ & AR & CD3ל & \\
\hline CD3 $\gamma$-deficientia* & $\mathrm{T}^{-} \mathrm{B}^{+} \mathrm{NK}^{+}$ & CD3G & $11 q 23$ & AR & $\mathrm{CD} 3 \gamma$ & \\
\hline CD45-deficientia & $\mathrm{T}^{-} \mathrm{B}+\mathrm{NK}^{-/+}$ & PTPRC & $1 \mathrm{q} 31.3$ & AR & CD45 (LCA) & \\
\hline ZAP70-deficientia* & $\begin{array}{l}\mathrm{T}^{+} \mathrm{B}^{+} \mathrm{NK}^{+} \\
\mathrm{CD}^{+} \\
\mathrm{CD}^{8-}\end{array}$ & ZAP70 & $2 q 11.2$ & AR & ZAP-70 & \\
\hline p56lck-deficientia & $\mathrm{T}^{-} \mathrm{B}^{+} \mathrm{NK}^{+}$ & LCK & $1 \mathrm{p} 35.1$ & $\mathrm{AR}$ & p56lck & \\
\hline
\end{tabular}

Csökkent lymphocytatúlélés, megnövekedett lymphocytaapoptózis vagy károsodott migráció vagy funkció

\begin{tabular}{|c|c|c|c|c|c|c|}
\hline Reticularis dysgenesis & $\mathrm{T}^{-} \mathrm{B}^{-} \mathrm{NK}^{-}$ & $\mathrm{AK} 2$ & 1 p34 & $\mathrm{AR}$ & Adenilát-kináz & $\begin{array}{l}\text { Aleukocytosis, sensorineuralis } \\
\text { süketség }\end{array}$ \\
\hline$A D A-S C I D$ & $\mathrm{~T}^{-} \mathrm{B}^{-} \mathrm{NK}^{-}$ & $\mathrm{ADA}$ & $20 \mathrm{ql} 13.11$ & $\mathrm{AR}$ & $\begin{array}{l}\text { Adenozin-deza- } \\
\text { mináz }\end{array}$ & $\begin{array}{l}\text { Csontrendszeri elváltozások, } \\
\text { neonatalis hepatitis, sensorineuralis } \\
\text { süketség, idegrendszeri eltérések }\end{array}$ \\
\hline PNP-SCID $^{\# \Phi}$ & $\mathrm{T}^{-} \mathrm{B}^{-} \mathrm{NK}^{-}$ & PNP & $14 \mathrm{q} 11.2$ & $\mathrm{AR}$ & $\begin{array}{l}\text { Purin-nukleozid- } \\
\text { foszforiláz }\end{array}$ & Idegrendszeri eltérések \\
\hline \multicolumn{7}{|c|}{ A thymus embryogenesisének defektusai } \\
\hline $\begin{array}{l}\text { Csupasz lymphocyta } \\
\text { szindróma (bare lymphocyte } \\
\text { syndrome, BLS)? }\end{array}$ & $\mathrm{T}^{-} \mathrm{B}^{+} \mathrm{NK}^{+}$ & WHN & $17 \mathrm{q} 11.2$ & $\mathrm{AR}$ & FOXN1 & $\begin{array}{l}\text { Alopecia, embrionális velőcsőfejlődési } \\
\text { zavarok }\end{array}$ \\
\hline \multicolumn{7}{|l|}{ Komplett Di George-anomália } \\
\hline $\begin{array}{l}\text { Di George-szindróma } \\
(\text { del22q11.2 })^{\text {I }}\end{array}$ & $\mathrm{T}^{-} \mathrm{B}^{+} \mathrm{NK}^{+}$ & >35 gén & $22 \mathrm{q} 11.2$ & $\mathrm{AD}$ & TBXl és egyéb & $\begin{array}{l}\text { Dysmorph facies, szívfejlődési } \\
\text { rendellenességek és egyéb malformá- } \\
\text { ciók, neonatalis hypocalcaemia, } \\
\text { mellékpajzsmirigy-hiány }\end{array}$ \\
\hline CHARGE ${ }^{\pi}$ & $\mathrm{T}^{-} \mathrm{B}^{+} \mathrm{NK}^{+}$ & CHD7 & $8 \mathrm{q} 12.1$ & $\mathrm{AD}$ & CHD-7 & $\begin{array}{l}\text { CHARGE-asszociáció (coloboma, } \\
\text { szívdefektus, atresia choanae, } \\
\text { növekedési és fejlődési retardáció, } \\
\text { genitalis hypoplasia, fül anomáliák/ } \\
\text { süketség) }\end{array}$ \\
\hline
\end{tabular}


1. táblázat folyt.

\begin{tabular}{|c|c|c|c|c|c|}
\hline Mechanizmus/Betegség & $\mathrm{T} / \mathrm{B} / \mathrm{NK}$ & Gén & Lokalizáció Öröklődés & Fehérje & Nem immunológiai manifesztációk \\
\hline $\begin{array}{l}\text { Anyai diabeteses } \\
\text { embryopathia }\end{array}$ & $\mathrm{T}^{-} \mathrm{B}^{+} \mathrm{NK}^{+}$ & & & & $\begin{array}{l}\text { Veleszületett szívfejlődési rendelle- } \\
\text { nesség, bél- és vesemalformációk, } \\
\text { velőcsődefektusok, sacralis agenesia, } \\
\text { holoprosencephalia, } \\
\text { neonatalis hypoglykaemia }\end{array}$ \\
\hline
\end{tabular}

Károsodott kalciumflux (CRAC-deficientia)

\begin{tabular}{|c|c|c|c|c|c|c|}
\hline $\begin{array}{l}\text { ORAIl-deficientia? } \\
\text { T-sejt-aktivációs deficientia, } \\
\text { norm. lymphocytafejlődés, } \\
\text { kivéve Treg és NKT }\end{array}$ & $\mathrm{T}^{+} \mathrm{B}^{+} \mathrm{NK}^{+}$ & ORAIl & $12 \mathrm{q} 24$ & $\mathrm{AR}$ & ORAII & $\begin{array}{l}\text { Autoimmunitás, myopathia, } \\
\text { ectodermalis dysplasia }\end{array}$ \\
\hline $\begin{array}{l}\text { STIMl-deficientia? } \\
\text { T-sejt-aktivációs deficientia, } \\
\text { norm. lymphocytafejlődés, } \\
\text { kivéve Treg és NKT }\end{array}$ & $\mathrm{T}^{+} \mathrm{B}^{+} \mathrm{NK}^{+}$ & STIMl & $11 \mathrm{p} 15.5$ & $\mathrm{AR}$ & STIMl & $\begin{array}{l}\text { Autoimmunitás, myopathia, } \\
\text { ectodermalis dysplasia }\end{array}$ \\
\hline \multicolumn{7}{|c|}{ Károsodott magnéziumflux (XMEN-deficientia) } \\
\hline $\begin{array}{l}\text { MAGTl-deficientia } \\
\text { T-sejt-aktivációs deficientia }\end{array}$ & $\begin{array}{l}\mathrm{T}^{+} \mathrm{B}^{+} \mathrm{NK}^{+} \\
\mathrm{CD}^{4-} \\
\mathrm{CD}^{8+} \\
\mathrm{CD} 4: \mathrm{CD} 8: \downarrow \\
\text { NKG2D- } \\
\text { expresszió } \downarrow\end{array}$ & MAGT1 & $\mathrm{Xq} 21.1$ & $\mathrm{XL}$ & MAGTl & EBV-infekció, neoplasma \\
\hline \multicolumn{7}{|l|}{ Egyéb mechanizmusok } \\
\hline Coronin-1A-deficientia" & $\mathrm{T}^{-} \mathrm{B}^{+} \mathrm{NK}^{+}$ & COROIA & $16 \mathrm{p} 11.2$ & $\mathrm{AR}$ & Coronin-1A & \\
\hline MHCII-deficientia* & $\begin{array}{l}\mathrm{T}^{+} \mathrm{B}^{+} \mathrm{NK}^{+} \\
\mathrm{CD}^{4-} \\
\mathrm{CD}^{8+}\end{array}$ & $\begin{array}{l}\text { CIITA } \\
\text { RFXANK } \\
\text { RFX5 } \\
\text { RFXAP }\end{array}$ & $\begin{array}{l}16 \mathrm{pl} 13.13 \\
19 \mathrm{pl} 13.11 \\
1 \mathrm{q} 21.2 \\
13 \mathrm{q} 13.3\end{array}$ & $\begin{array}{l}\mathrm{AR} \\
\mathrm{AR} \\
\mathrm{AR} \\
\mathrm{AR}\end{array}$ & $\begin{array}{l}\text { CIITA } \\
\text { RFXANK } \\
\text { RFX5 } \\
\text { RFXAP }\end{array}$ & \\
\hline $\begin{array}{l}\text { Porc-haj hypoplasia } \\
\text { (Cartilage hair hypoplasia, } \\
\mathrm{CHH})^{\#}\end{array}$ & $\mathrm{~T}^{-} \mathrm{B}^{+} \mathrm{NK}^{+}$ & RMRP & $9 \mathrm{p} 13.3$ & AR & $\begin{array}{l}\text { RNA of } \\
\text { RNase MRP } \\
\text { komplex }\end{array}$ & $\begin{array}{l}\text { Rövid végtagú törpeség, világos } \\
\text { hypoplasiás haj }\end{array}$ \\
\hline Ataxia telangiectasia $(\mathrm{AT})^{\star \#}$ & $\mathrm{~T} \downarrow$ & ATM & $11 q 22-23$ & $\mathrm{AR}$ & $\begin{array}{l}\text { Ataxia telangiec- } \\
\text { tasia mutated }\end{array}$ & $\begin{array}{l}\text { Progresszív cerebellaris ataxia, } \\
\text { oculocutan telangiectasia, radioszen- } \\
\text { zitivitás, kromoszómainstabilitás }\end{array}$ \\
\hline $\begin{array}{l}\text { Nijmegen breakage szindró- } \\
\text { ma (NBS)*\# }\end{array}$ & $\mathrm{T} \downarrow$ & NBN & $8 \mathrm{q} 21$ & $\mathrm{AR}$ & Nibrin & $\begin{array}{l}\text { Dysmorph facies, microcephalia, } \\
\text { növekedési retardáció, központi } \\
\text { idegrendszeri, nemi szervi és } \\
\text { urogenitalis fejlődési rendellenességek }\end{array}$ \\
\hline $\begin{array}{l}\text { Hoyeraal-Hreidarsson-szind- } \\
\text { róma (HHS)? }\end{array}$ & $\mathrm{T}^{+} \mathrm{B}^{-} \mathrm{NK}^{-}$ & $\begin{array}{l}\text { DKCl } \\
\text { TERT } \\
\text { TINF2 } \\
\text { DCLRE1B }\end{array}$ & $\begin{array}{l}\mathrm{Xq} 28 \\
5 \mathrm{p} 15.33 \\
14 \mathrm{q} 12 \\
1 \mathrm{p} 13.2 \\
\end{array}$ & $\begin{array}{l}\mathrm{XL} \\
\mathrm{AR} \\
\mathrm{AD} \\
\mathrm{AD}\end{array}$ & $\begin{array}{l}\text { Dyskerin } \\
\text { TERT } \\
\text { TIN2 } \\
\text { Apollo }\end{array}$ & $\begin{array}{l}\text { Cerebellaris hypoplasia, microce- } \\
\text { phalia, növekedési retardáció, } \\
\text { csontvelő-elégtelenség, hajhypoplasia }\end{array}$ \\
\hline $\begin{array}{l}\text { Öröklött folsavmalabszorpció } \\
\text { (hereditary folate malabsorp- } \\
\text { tion, HFM)? }\end{array}$ & $\mathrm{T}^{+} \mathrm{B}^{+} \mathrm{NK}^{+}$ & SLC46Al & $17 \mathrm{q} 11.2$ & $\mathrm{AR}$ & PCFT & $\begin{array}{l}\text { Megaloblastos anaemia, epilepsziás } \\
\text { roham, súlyos idegrendszeri fejlődési } \\
\text { rendellenességek }\end{array}$ \\
\hline
\end{tabular}

Jelölések:

Dőlt betü: A betegség bizonyítottan kimutatható újszülöttkori TREC-szúrővizsgálattal.

*: A betegség TREC-vizsgálattal nem mutatható ki (a TCR-rekombináció intakt, a TREC-képződés fiziológiás).

\#: Az intakt TREC-képződés ellenére a csökkent perifériás T-sejt-szám miatt (csökkent képzőódés a thymusban vagy csökkent túlélés a periférián) TREC-vizsgálattal kimutatható a betegség.

؟: A patomechanizmus alapján TREC-vizsgálattal a betegség feltételezetten szűrhető, de eddig ezzel a módszerrel ilyen beteget még nem diagnosztizáltak.

?: Nincs elegendő adat a TREC-vizsgálattal kapcsolatban.

Kevés adat áll rendelkezésre a kategorizáláshoz: STAT5b-deficientia, MHCI-deficientia, ITK-deficientia.

$\mathrm{AD}=$ autosomal dominant $\mathrm{ADA}=$ adenosine deaminase; $\mathrm{AR}=$ autosomal recessive $\mathrm{CD}=$ cluster of differentiation, cell differentiation antigen; CHARGE = coloboma, heart defects, atresia choanae, retardated growth and development, genital hypoplasia, ear anomalies $/$ deafness; CRAC = $\mathrm{Ca}^{2+}$ release-activated $\mathrm{Ca}^{2+}$ channel; DNA-PKcs $=$ DNA-dependent protein kinase, catalytic subunit; IL7R = interleukin-7 receptor; JAK $=$ Janus kinase; $\mathrm{MAGT1}=\mathrm{Mg}^{2+}$ transporter; $\mathrm{MHC}=$ major histocompatibility complex; NKG2D = natural killer group 2; p56lck = lymphocyte-specific protein tyrosine kinase; $\mathrm{PNP}=$ purine nucleoside phosphorylase; $\mathrm{RAG}=$ recombination activating gene; $\mathrm{XL}=\mathrm{X}$-linked; $\mathrm{XMEN}=\mathrm{X}$-linked immunodeficiency with $\mathrm{Mg}^{2+}$ deficientia; $\mathrm{ZAP}=$ zeta-chain-associated protein 
teljesen hiányzik, így transzplantáció előtt kemoterápiára vagy sugárkezelésre nincs szükség. Fontos, hogy a SCIDben szenvedő betegek kizárólag fehérvérsejt-depletált, azaz szûrt és irradiált vérkészítménnyel transzfundálhatók. Nem kaphatnak élő kórokozót tartalmazó vakcinát (például BCG-oltás, rotavírusvakcina), amely esetükben életveszélyes fertőzést is okozhat! Az újszülöttkori SCID-szürés bevezetésének kérdése a Magyarországon kötelezően alkalmazott BCG-oltás miatt is döntő fontosságú, hiszen negatív családi anamnézisű beteg újszülött esetében az oltás halálos kimenetelü fertőzéshez vezethet. Több országban az újszülöttkori BCG-oltás eltörléséhez több más körülmény mellett ennek ismerete is hozzájárult [5].

Mivel a SCID miatt érintett csecsemók születéskor egészségesnek tünnek, korábban csak a pozitív családi anamnézisü csecsemőkben volt lehetőség korai diagnózisra, amely az összes eset kevesebb, mint 20\%-át jelentette [10-12]. Az elmúlt évtizedek transzplantációs tapasztalatai bizonyították, hogy az idejekorán, még a súlyos, nehezen kezelhető fertőzések és a visszafordíthatatlan szervi károsodások kialakulását megelőzően, tünetmentes időszakban végzett beavatkozások a legoptimálisabb kimenetelúek [10, 13-15]. A korai felismerés jelentőségét jól érzékelteti, hogy a pozitív családi anamnézisű, ennek köszönhetően korábban kiszűrt csecsemók túlélése 90\%-os, míg a sporadikus esetekben az életkilátás lényegesen rosszabb, a túlélés mindössze $40 \%$ körüli $[7,10,14]$.

\section{A SCID epidemiológiája}

A SCID újszülöttkori szưrővizsgálatának szélesebb körü bevezetését megelőzően a SCID előfordulási gyakoriságát 1/100 000-re becsülték [11, 16]. Konkrét etnikai csoportokban ismert a betegség magasabb incidenciája, így például a szomáliai lakosságban az ADA-SCID elöfordulása 1/5000 [17], a navahó amerikaiak között a DCLRElC (Artemis)-gén-mutációk 1/2000 gyakorisággal fordulnak elő [18], míg a RAG1, RAG2, ADA, IL7R, CD3 és ZAP70 mutációk az amis és a mennonita populációban gyakoribbak $[19,20]$. Mivel a súlyos opportunista fertőzések következtében a betegség már a felismerését megelőzően halálos kimenetelü lehet, azokban az országokban, ahol az újszülöttkori szúrés még nem került bevezetésre, az előfordulási gyakoriság minden bizonnyal alábecsült.

\section{A SCID molekuláris genetikája és a SCID-szürés kezdetei}

A SCID és a CID (combined immunodeficiency, kombinált immunhiányos betegség) genetikailag heterogén betegségcsoportok, amelynek ismerete fontos a szűrővizsgálati módszerek kiválasztásának és lehetséges korlátainak megértéséhez. Napjainkban több mint 30 gén is- mert, amelyek mutációja a T- és B-sejtes immunválasz károsodásához vezet (1. táblázat) [21, 22]. SCID esetében olyan szûrőmódszer bevezetése célszerü, amely nemcsak megalapozott, megbízható és költséghatékony, de illeszthető a jelenlegi magyarországi szűrőprogramba [23], például azáltal, hogy az anyagcsere-betegségekhez hasonlóan a vizsgálat szárított vérmintából elvégezhető, így a költségek csökkenthetők, és a többszöri mintavétel elkerülhető.

A SCID-szűrés kezdetei az 1970-es évekre tehetők, amikor ADA-SCID szúrésére a beszárított vérmintából kolorimetriás enzimvizsgálatot végeztek, de ezek a vizsgálatok a gyakori álnegatív, illetve álpozitív esetek miatt nem terjedtek el $[21,24]$. Lehetséges biomarkerként a döntően a csontvelő és a thymus stromasejtjei által termelt interleukin-7 (IL7) szerepe is felmerült, ugyanis több esetben ezen citokin emelkedett szintjét figyelték meg SCID-ben és szerzett lymphopeniákban [25, 26]. Az IL7 szárított vérmintában tapasztalt korlátozott stabilitása miatt azonban ez a teszt sem válhatott szürőmódszerré, hasonlóan a $\mathrm{CD}^{3+}$ és a $\mathrm{CD}^{45+} \mathrm{T}$-sejtek, illetve a teljes leukocytaszám újszülöttkori vizsgálatához [27].

$\mathrm{Az}$ ismert SCID-betegségi gének korábban már leírt, illetve eddig még nem ismert DNS-szekvencia-variánsainak kimutatása beszárított vérmintából multiplex génpanelek alkalmazásával DNS-microarray-technika segítségével elviekben egy lehetséges szürési mód [28]. A vizsgálat szürésként történő gyakorlati bevezetését azonban korlátozza, hogy több száz az ismert SCIDgén-mutációk száma, és az új szekvenciavariánsok is gyakoriak. Ráadásul sok beteg esetében a kiterjesztett génszekvenálás ellenére sem sikerül a mutációt azonosítani. A rendkívüli genetikai heterogenitás miatt tehát a DNSmicroarray-technika nem ideális SCID-szúrési módszer, hiszen ha egy-egy konkrét mutációs szürőpanelre (mutációkatalógusra) támaszkodunk, lesznek fel nem ismert betegek [29]. További probléma, hogy insertiók és deletiók esetében a módszer szenzitivitása nem megfelelő. A teljesexom-, illetve teljesgenom-szekvenálás esetében az álnegativitás lehetősége magasabb, a módszer költséges, továbbá hosszabb idő szükséges a vizsgálat elvégzéséhez és az eredmények kiértékeléséhez.

Mivel a SCID genetikailag heterogén betegség, de döntően a T-sejtek hiányoznak, vagy számuk alacsony, minden szempontból célravezetőbb első szürőlépésként ezen sejtcsoport vizsgálata. Az abszolútlymphocytaszám (absolute lymphocyte count, ALC) jó szûrőmarkernek tûnhet, hiszen a legtöbb SCID-es újszülöttben az ALC - amelynek többségét a $\mathrm{CD}^{3+} \mathrm{T}$-sejtek teszik ki - alacsony. Ugyanakkor a SCID bizonyos formáiban az ALC-érték normális vagy akár emelkedett is lehet. Annak érdekében, hogy minden eset felismerésre kerüljön, az ALC alsó határértékét magasabbra kellene beállítani, ez azonban az álpozitivitást növelné [29]. A beszárított vérminták kezelése lényegesen olcsóbb is, a folyékony vérmintákéval összehasonlítva. Mindezek miatt az ALC-meghatározás nem alkalmas populációs szin- 
tû szûrővizsgálatra. Elviekben a lymphocytapopulációk szûrővizsgálata köldökzsinórvér felhasználásával is történhetne, de ez a szülések sokszor bizonytalan ideje és az áramlási citometriás vizsgálathoz szükséges friss vérminta miatt folyamatos laboratóriumi készenlétet igényel, így jelentős pénzügyi kihatással jár, és logisztikai nehézségeket is okozhat [30].

\section{A TREC-teszt}

Az antigénspecifikus T- és B-sejtek nagymértékű diverzitása kritikus lépés a kellően széles immunrepertoár (az egyedi antigénkötő receptorral rendelkező T-, illetve Bsejt-klónok összessége) kialakulásához. Ezt a diverzitást az antigénfelismerő receptorláncok génjeinek szomatikus átrendeződése (szomatikus rekombináció) biztosítja. Ennek a folyamatnak köszönhetően még az antigénnel való találkozást megelőzően egyénenként körülbelül $10^{9}$ különböző antigénspecificitású T- és B-sejt-klón alakul ki, így az immunrendszer képessé válik a környezetünkben előforduló antigének felismerésére. Az óriási diverzitás ellenére minden egyes T- és B-sejt-klón monospecifikus, azaz csak egyetlen antigénre specifikus receptort (BCR, illetve TCR) expresszál.

A különböző antigénspecificitású receptorok milliárdjainak kódolására a teljes genom nem lenne elegendő, ugyanakkor a DNS-splicing révén megvalósuló szomatikus génátrendeződés biztosítja a 4 TCR-, illetve a 3 BCR-gén-locus variálódását még az éretlen T-sejtekben (a thymusban), illetve B-sejtekben (a csontvelőben). Ennek során egyetlen génszegmens véletlenszerüen kiválasztódik, majd DNS kettős szálú törések, illetve újrakötődés révén a DNS egy további szakaszához kapcsolódik [31]. A funkcionális receptort kódoló génszakaszokon kívüli, köztes DNS-részek (intronok) pedig felcsavarodva cirkulárissá válnak (signal joint T-cell receptor excision circle, sjTREC). A TREC stabil, a mitózis során nem replikálódik, így a T-sejt-proliferáció során a kópiaszám arányosan csökken $[32,33]$. Mire a csecsemőmirigy elsorvad, a sjTREC-szint is jelentősen lecsökken, egészséges újszülöttben azonban még magas értékek mérhetők.

A fentiek miatt érthető, hogy napjainkra a SCID szürésében szóba jövő módszerek közül a TREC-vizsgálatot javasolják, amelyet eredetileg antiretrovirális terápiában részesülő HIV-fertőzöttek T-sejt-képződésének monitorizálására dolgoztak ki [32]. A TREC kvantitatív vizsgálata szorosan kapcsolódhat az anyagcsere-betegségek jelenlegi magyarországi tömeg-szűrővizsgálatához, hiszen azokhoz hasonlóan szürőpapíros vérmintából megoldható. A szűrőpapíros vérminta alkalmas postai úton történő szállításra és a vizsgálat többszöri megismétlésére is. A genomiális DNS izolálása a szưrőpapíros vérminta fehérvérsejtjeiből is lehetséges, bár ma már forgalomban vannak olyan TREC-kitek is, amelyeknél nincs szükség az örökítőanyag kivonására. RT-PCR- (real-time polymerase chain reaction, valós idejű polimeráz-láncreakció) vizsgálattal egyszerúen meghatározható a TREC értéke, amely így a T-sejt-képzés egyik biomarkere. A TREC-teszt érzékenyen jelzi a T-sejt-termelés, illetve a kóros perifériás T-sejt-vesztés mértékét. Az RT-PCR során a kontrollprimerek egy független genomiális DNSszegmenst ( $\beta$-aktin vagy RNaseP-gén) is amplifikálnak, annak érdekében, hogy a szárított vérmintából kivont DNS minősége ellenőrizhető legyen. A kontrollvizsgálattal kizárható vagy megerősíthető annak a lehetősége, hogy az alacsony TREC-értéket az elégtelen mennyiségü vagy rossz minőségű kivont DNS okozza [29].

A TREC-módszer SCID esetében megfelel a populációszintű szűrôvizsgálatokkal szemben támasztott követelményeknek, mivel alkalmazásával az abszolút minimumon tartható az álnegatív esetek száma, és az álpozitivitás is ritka. A TREC-vizsgálatnak köszönhetően a SCID lett az első primer immunhiányos betegség, amely újszülöttkori szúrőprogramba került $[34,35]$, és egyidejüleg a TREC lett az első úgynevezett ,high throughput” (nagy mintaszámon is alkalmazható) DNS-alapú teszt, amelyet újszülöttkori szürésre alkalmaztak [36]. Ma több TRECkit is hozzáférhető, ami jelentősen leegyszerüsíti a módszer kivitelezését. Hangsúlyozandó, hogy a TREC-hez hasonló módszerrel ( $\kappa$-lánc-kimetszés-körök, KRECs) már B-sejt-hiánnyal járó immundeficientiák (például Xkromoszómához kötött agammaglobulinaemia, XLA) is szûrhetők, de ezen szưrőmódszer esetében még sok kérdés nyitott, így esetleges populációs szintű bevezetése még további elemzéseket igényel.

\section{A TREC-teszttel szürhető betegségek}

A TREC-szúrőmódszer bevezetéséhez fontos azon kórképek ismerete, amelyek bizonyítottan vagy várhatóan hiányzó vagy csökkent TREC-értékkel társulnak, így a módszerrel kiszưrhetők (1. táblázat). Abban az esetben, ha a génhiba VDJ rekombinációt megelőző sejtfejlődési stádiumot érinti, a betegség alacsony TREC-értékkel társul [29, 36]. Bár az úgynevezett „leaky”, vagyis inkomplett SCID-esetekben részleges T-sejt-fejlődés előfordul, a betegség TREC-teszttel mégis szürhető, mivel a TREC-érték jóval a határérték alatt marad [37]. Fontos megjegyezni, hogy a SCID-nél enyhébb klinikai megjelenésü, de azzal gyakori átfedést mutató CID-nek vannak olyan genetikai formái (például ZAP70-deficientia, MHCII-deficientia), amelyekben a mutáció a TCRrekombinációt követő T-sejt-fejlődési lépéseket szabályozó géneket érinti. Ezekben az esetekben a T-sejt-szám normális vagy közel normális, de bizonyos effektorfunkciók sérülnek, mint a migráció, az antigén-válaszkészség, a citokintermelés, a proliferáció, a túlélés és az immunmemória. A T-sejt funkciózavara miatt az újszülöttkori fenotípus a SCID-hez hasonló lehet, de tekintettel a fiziológiás TREC-értékre, a betegség ezzel a módszerrel nem szürhető $[36,38,39]$.

A TREC-teszt másodlagos célcsoportjába (non-SCID TCL) olyan betegségek tartoznak, amelyekre a SCIDhez hasonlóan újszülöttkori T-sejtes lymphopenia és ala- 
csony TREC-érték jellemző [29]. Ilyen például néhány jól meghatározott genetikai szindróma, amelyben a Tsejtek képződése károsodott, mint a Di George-szindróma, a 21 -es kromoszóma triszómiája vagy a CHARGE (congenital heart defect, atresia choanae, retarded growth and development, genital abnormality, and ear abnormality). Ezen kórképek esetében azonban az érintett újszülötteknek csak egy kis részében kellően alacsony a T-sejtek száma ahhoz, hogy TREC-teszttel azonosítható legyen. Azokban a szúrő́centrumokban, ahol a kriti-

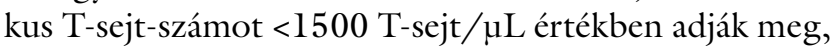
a Di George-szindrómás újszülötteknek csak körülbelül 5\%-a szúrhetố ki [40]. A TCL szekunder okai között szerepelhet lymphangiectasia, intestinalis és újszülöttkori leukaemia, amelyekben a fokozott vesztés, illetve a csontvelő-infiltráció miatt alacsony a T-sejtek száma [40]. A 30. terhességi hetet megelőzően született, 1500 grammnál kisebb súlyú koraszülötteknél is előfordulhat átmeneti lymphopenia, amely a későbbiekben normalizálódik [40].

\section{Következtetés}

A SCID újszülöttkori szứrővizsgálatának köszönhetően a betegség már preszimptomatikusan felismerhetô, így a korábbi, elsősorban a növekedési retardációt, az opportunista és súlyos fertôzéseket, illetve a lymphopeniát hangsúlyozó definíció helyett új, döntően a laboratóriumi eltéréseken és kevésbé az infekciós szövődményeken nyugvó kritériumok megalkotására volt szükség. A Primary Immune Deficiency Treatment Consortium (PIDTC) által meghatározott betegségi kritériumok az alábbiak: $<300$ autológ T-sejt $/ \mu \mathrm{L},<10 \%$ PHA-stimulált lymphocytatranszformáció, gyakori anyai T-sejt-megtapadás és ismert SCID-gén-mutáció [12, 41].

A szürő́vizsgálat bevezetése előtt a SCID-genotípus eloszlása az X-kromoszómához kötött IL2RG-gén-mutációk dominanciáját mutatta. Ezzel szemben az újszülöttkori szürővizsgálatok eredményei az autoszomális recesszív génhibák gyakoribb előfordulását jelzik, valószínúleg a negatív családi anamnézisú sporadikus esetek jobb felismerésének köszönhetően (1. ábra) [37, 42, 43]. A szűrővizsgálatokkal az incidencia is pontosabban meghatározhatóvá vált. Kwan és mtsai szerint 58 ezer újszülöttbőll 1 érintett SCID vagy inkomplett SCID miatt, ami közel a kétszerese annak, amit megelőzően a transzplantációs centrumok statisztikai adatai jeleztek [37]. A populációs szintű TREC-szürés fontos hozadéka korábban nem ismert SCID-gének azonosítása, mint például a TTC7A-gén, amely az immundeficientia mellett multiplex bélatresiával társul $[44,45]$. Fontos felismerés volt továbbá, hogy legalább az esetek felében az ataxia telangiectasiás betegeket TREC-szüréssel azonosítani lehet [46]. A szürést megelőző időszakhoz képest ugyanakkor nagyobb azon esetek előfordulása is, amelyekben SCID-gén-mutáció kiterjesztett génszekvenálással sem azonosítható $[36,38-40]$.
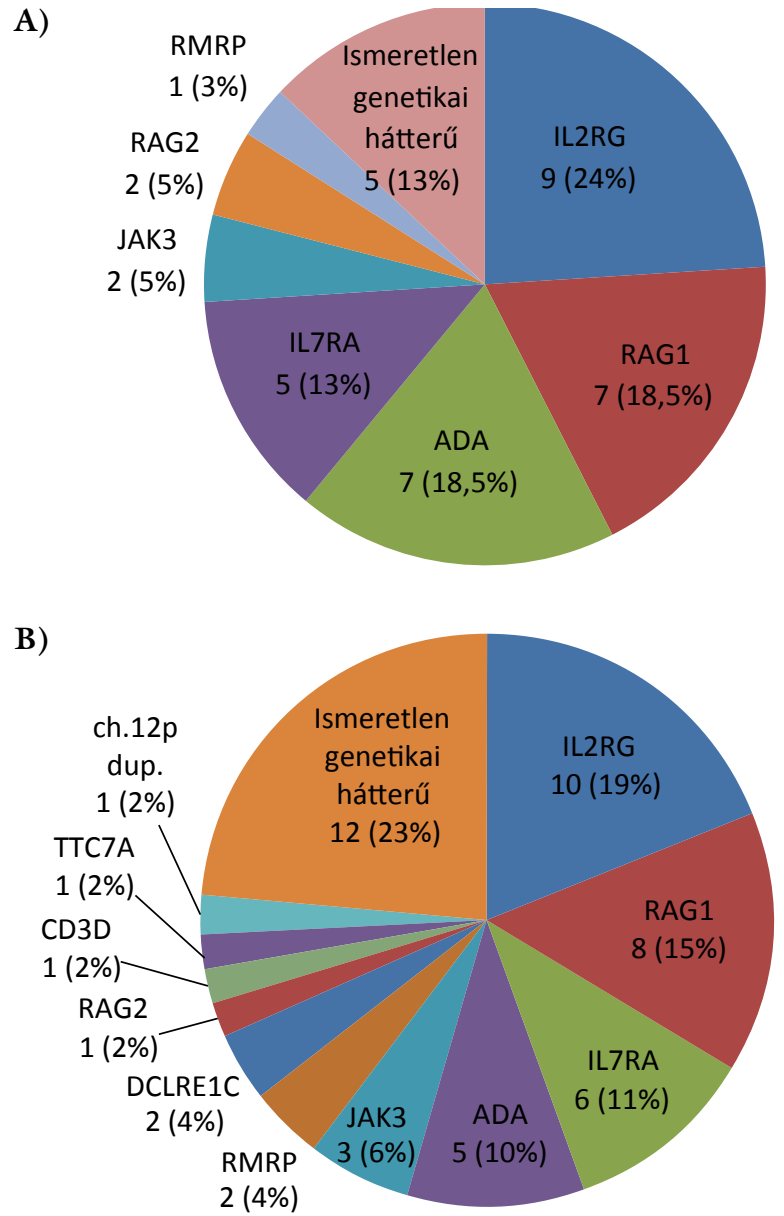

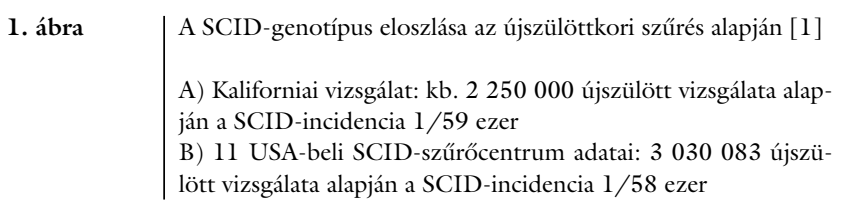

A SCID újszülöttkorban történő szűrővizsgálatának szükségessége nem kérdőjelezhező meg. Az idejekorán történő felismerés döntő jelentőségú abban, hogy az életmentő kezelés még a visszafordíthatatlan szervi károsodások kialakulását megelőző tünetmentes időszakban elkezdődhessen, így közel 100\%-os túlélést biztosítva [7, $10,14]$. A korai, genetikai szintú diagnózis abban is segít, hogy kiválasszuk az adott SCID-altípusnak leginkább megfelelő kezelési stratégiát (donorsejtek T-sejtdepléciója, kondicionáló kezelés stb.). Erre jó példa a RAG-deficientia, illetve az Artemis-SCID, amelyekben az azonos fenotípus ellenére az alkilezőszerek toxicitásával szembeni érzékenység eltérő [47]. Azon újszülöttek esetében, akikben bármely okból adódóan csökkent Tsejt-szám igazolódik, a korai felismeréssel a diagnózis megszületéséig is elkerülhető az élő kórokozót tartalmazó vakcinák beadása, transzfúzióigény esetén biztosítható az irradiált vérkészítmény, és szükség esetén infekcióprofilaxis alkalmazható, vagy immunglobulin adható $[6$, $48]$. 
Anyagi támogatás: A közlemény megírása, illetve a kapcsolódó kutatómunka anyagi támogatásban nem részesült.

A cikk végleges változatát a szerző elolvasta és jóváhagyta.

Érdekeltségek: A szerzőnek nincsenek érdekeltségei.

\section{Irodalom}

[1] Kwan A, Puck J. History and current status of newborn screen ing for severe combined immunodeficiency. Semin Perinatol. 2015; 39: 194-205.

[2] Advisory Committee on Heritable Disorders in Newborns and Children. Available from: https://www.hrsa.gov/advisorycommittees/mchbadvisory/heritabledisorders/

[3] Wilson JM, Jungner YG. Principles and practice of mass screening for disease. Bol Oficina Sanit Panam. 1968; 65: 281-393.

[4] Maródi L, Karmazsin L. Possibilities of prenatal diagnosis in primary immunodeficiencies. [A prenatalis diagnosztika lehetőségei primer immundefektusokban.] Orv Hetil. 1986; 127: 2937 2940. [Hungarian]

[5] Maródi L. Immunodeficiencies. In: Maródi L. (ed.) Pediatrics. [Immundefektusok. In: Maródi L. (szerk.) Gyermekgyógyászat.] Medicina Könyvkiadó, Budapest, 2013; pp. 457-490. [Hungarian]

[6] Bakare N, Menschik D, Tiernan R, et al. Severe combined immunodeficiency (SCID) and rotavirus vaccination: reports to the Vaccine Adverse Events Reporting System (VAERS). Vaccine 2010; 28: 6609-6612.

[7] Notarangelo LD. Primary immunodeficiencies. J Allergy Clin Immunol. 2010; 125(Suppl 2): S182-S194.

[8] Matsubara Y, Chiba T, Kashimada K, et al. Transcription activator-like effector nuclease-mediated transduction of exogenous gene into IL2RG locus. Sci Rep. 2014; 4: 5043.

[9] Genovese P, Schiroli G, Escobar G, et al. Targeted genome editing in human repopulating haematopoietic stem cells. Nature 2014; 510: 235-240.

[10] Chan A, Scalchunes C, Boyle M, et al. Early vs. delayed diagnosis of severe combined immunodeficiency: a family perspective survev. Clin Immunol. 2011; 138: 3-8.

[11] Buckley RH, Schiff RI, Schiff SE, et al. Human severe combined immunodeficiency: genetic, phenotypic, and functional diversity in one hundred eight infants. J Pediatr. 1997; 130: 378-387.

[12] Dvorak CC, Cowan MJ, Logan BR, et al. The natural history of children with severe combined immunodeficiency: baseline features of the first fifty patients of the Primary Immune Deficiency Treatment Consortium Prospective Study 6901. J Clin Immunol. 2013; 33: 1156-1164

[13] Myers LA, Patel DD, Puck JM, et al. Hematopoietic stem cell transplantation for severe combined immunodeficiency in the neonatal period leads to superior thymic output and improved survival. Blood 2002; 99: 872-878.

[14] Brown L, Xu-Bayford J, Allwood Z, et al. Neonatal diagnosis of severe combined immunodeficiency leads to significantly improved survival outcome: the case for newborn screening. Blood 2011; 117: 3243-3246.

[15] Pai SY, Logan BR, Griffith LM, et al. Transplantation outcomes for severe combined immunodeficiency, 2000-2009. N Engl J Med. 2014; 371: 434-446.

[16] Stephan JL, Vlekova V, Le Deist F, et al. Severe combined immunodeficiency: a retrospective single-center study of clinical presentation and outcome in 117 patients. J Pediatr. 1993; 123: 564-572.

[17] Sanchez JJ, Monaghan G, Børsting C, et al. Carrier frequency of a nonsense mutation in the adenosine deaminase (ADA) gene implies a high incidence of ADA-deficient severe combined im munodeficiency (SCID) in Somalia and a single, common haplotype indicates common ancestry. Ann Hum Genet. 2007; 71: 336-347.

[18] Jones JF, Ritenbaugh CK, Spence MA, et al. Severe combined immunodeficiency among the Navajo. I. Characterization of phenotypes, epidemiology, and population genetics. Hum Biol. 1991; 63: 669-682.

[19] Morton DH, Morton CS, Strauss KA, et al. Pediatric medicine and the genetic disorders of the Amish and Mennonite people of Pennsylvannia. Am J Med Genet. 2003; 121C: 5-17.

[20] Jilkina O, Thompson JR, Kwan L, et al. Retrospective TREC testing of newborns with severe combined immunodeficiency and other primary immunodeficiency diseases. Mol Genet Metab Rep. 2014; 1: 324-333.

[21] Kalman L, Lindegren ML, Kobrynski L, et al. Mutations in genes required for T-cell development: IL7R, CD45, IL2RG, JAK3, RAG1, RAG2, ARTEMIS, and ADA and severe combined immunodeficiency: HuGE review. Genet Med. 2004; 6: 16-26.

[22] Al-Herz W, Bousfiha A, Casanova JL, et al. Primary immunodeficiency diseases: an update on the classification from the International Union of Immunological Societies Expert Committee for Primary Immunodeficiency. Front Immunol. 2014; 5: 162.

[23] Szabó E, Balogh L, Szabó A, et al. Diagnostics of inborn errors of metabolism: laboratory approaches. [Ritka örökletes anyagcsere-betegségek diagnosztikája: laboratóriumi vizsgálati megközelítések.] Orv Hetil. 2017; 158: 1903-1907. [Hungarian]

[24] Hirschhorn R. Adenosine deaminase deficiency. Immunodefic Rev. 1990; 2: 175-198.

[25] Bolotin E, Annett G, Parkman R, et al. Serum levels of IL-7 in bone marrow transplant recipients: relationship to clinical characteristics and lymphocyte count. Bone Marrow Transplant. 1999; 23: 783-788.

[26] McGhee SA, Stiehm ER, Cowan M, et al. Two-tiered universal newborn screening strategy for severe combined immunodeficiency. Mol Genet Metab. 2005; 86: 427-430.

[27] Janik DK, Lindau-Shepard B, Comeau AM, et al. A multiplex immunoassay using the Guthrie specimen to detect T-cell deficiencies including severe combined immunodeficiency disease. Clin Chem. 2010; 56: 1460-1465.

[28] Lebet T, Chiles R, Hsu AP, et al. Mutations causing severe combined immunodeficiency: detection with a custom resequencing microarray. Genet Med. 2008; 10: 575-585.

[29] Puck JM. Laboratory technology for population-based screening for severe combined immunodeficiency in neonates: the winner is T-cell receptor excision circles. J Allergy Clin Immunol. 2012; 129: 607-616.

[30] Collier F, Tang M, Ponsonby AL, et al. Flow cytometric assessment of cord blood as an alternative strategy for populationbased screening of severe combined immunodeficiency. J Allergy Clin Immunol. 2013; 131: 1251-1252.

[31] de Villartay JP. V(D)J recombination deficiencies. Adv Exp Med Biol. 2009; 650: 46-58.

[32] Douek DC, McFarland RD, Keiser PH, et al. Changes in thymic function with age and during the treatment of HIV infection. Nature 1998; 396: 690-695.

[33] Hazenberg MD, Otto SA, Cohen Stuart JW, et al. Increased cell division but not thymic dysfunction rapidly affects the T-cell receptor excision circle content of the naive $\mathrm{T}$ cell population in HIV-1 infection. Nat Med. 2000; 6: 1036-1042.

[34] Chan K, Puck JM. Development of population-based newborn screening for severe combined immunodeficiency. J Allergy Clin Immunol. 2005; 115: 391-398.

[35] Morinishi Y, Imai K, Nakagawa N, et al. Identification of severe combined immunodeficiency by $\mathrm{T}$-cell receptor excision circles quantification using neonatal Guthrie cards. J Pediatr. 2009; 155: 829-833. 
[36] Kwan A, Puck JM. Newborn screening for severe combined immunodeficiency. Cur Pediatr Rep. 2015; 3: 34-42.

[37] Kwan A, Abraham RS, Currier R, et al. Newborn screening for severe combined immunodeficiency in 11 screening programs in the United States. JAMA 2014; 312: 729-738.

[38] Grazioli S, Bennett M, Hildebrand KJ, et al. Limitation of TREC-based newborn screening for ZAP70 severe combined immunodeficiency. Clin Immunol. 2014; 153: 209-210.

[39] Kuo CY, Chase J, Lloret MG, et al. Newborn screening for severe combined immunodeficiency does not identify bare lymphocyte syndrome. J Allergy Clin Immunol. 2013; 131: 16931695.

[40] Kwan A, Church JA, Cowan MJ, et al. Newborn screening for severe combined immunodeficiency and T-cell lymphopenia in California: Results of the first 2 years. J Allergy Clin Immunol. 2013; 132: 140-150.

[41] Shearer WT, Dunn E, Notarangelo LD, et al. Establishing diagnostic criteria for severe combined immunodeficiency disease (SCID), leaky SCID, and Omenn syndrome: the Primary Immune Deficiency Treatment Consortium experience. J Allergy Clin Immunol. 2014; 133: 1092-1098.

[42] Griffith LM, Cowan MJ, Kohn DB, et al. Allogeneic hematopoietic cell transplantation for primary immune deficiency diseases: current status and critical needs. J Allergy Clin Immunol. 2008; 122: 1087-1096.

[43] Buckley RH. Molecular defects in human severe combined immunodeficiency and approaches to immune reconstitution. Ann Rev Immunol. 2004; 22: 625-655.
[44] Samuels ME, Majewski J, Alirezaie N, et al. Exome sequencing identifies mutations in the gene TTC7A in French-Canadian cases with hereditary multiple intestinal atresia. J Med Genet. 2013; 50: 324-329.

[45] Chen R, Giliani S, Lanzi G, et al. Whole-exome sequencing identifies tetratricopeptide repeat domain 7A (TTC7A) mutations for combined immunodeficiency with intestinal atresias. J Allergy Clin Immunol. 2013; 132: 656-664.

[46] Mallott J, Kwan A, Church J, et al. Newborn screening for SCID identifies patients with ataxia telangiectasia. J Clin Immunol. 2013; 33: 540-549.

[47] Schuetz C, Neven B, Dvorak CC, et al. SCID patients with ARTEMIS vs RAG deficiencies following HCT: increased risk of late toxicity in ARTEMIS-deficient SCID. Blood 2014; 123: 281-289.

[48] Shearer WT, Fleisher TA, Buckley RH, et al. Recommendations for live viral and bacterial vaccines in immunodeficient patients and their close contacts. J Allergy Clin Immunol. 2014; 133: 961-966.

\section{Az Orvosi Hetilap 2018, 159, 731. oldalán (18. szám) megjelent OH-Kvízre két helyes megfejtés érkezett.}

(Erdős Melinda dr., The Rockefeller University, 1230 York Avenue, Box 163,

New York, NY 10065, USA e-mail: merdos@rockefeller.edu)

A nyerteseknek szívböl gratulálunk.

\section{A rendezvények és kongresszusok híranyagának leadása}

a lap megjelenése előtt legalább 40 nappal lehetséges, a 6 hetes nyomdai átfutás miatt. Kérjük megrendelőink szíves megértését.

A híranyagokat a következő címre kérjük:

Orvosi Hetilap titkársága: edit.budai@akademiai.hu

Akadémiai Kiadó Zrt. 